\title{
Effct of Strontium Fluoride on the Synthetic Process of Zircon
}

\author{
Shin Yamamoto, Katsuki Yoshimura, Yukio Nurishi and Taizo Hibino \\ Department of Industrial Chemistry, Faculty of Engineering \\ Gifu University ; Kagamigahara-shi, Gifu, Japan
}

The effect af strontium fluoride on the synthetic process of zircon from silica and zirconia was investigated. Mixtures of various amount of silica, zirconia and strontium fluoride were heated in air and $\mathrm{HF}$ gas or $\mathrm{SiF}_{4}$ gas atmosphere. The samples obtained were examined by $\mathrm{X}$-ray diffraction method, $\mathrm{X}$-ray diffraction at high temperature, infra-red spectroscopic method and differential thermal analytical method. The migration of various species were observed by tablet method.

The following results were obtained.

Strontium fluride accelerates the synthetic process of zircon from silica and zirconia. In this reaction process, strontium fluoride reacts with silica and zirconia to form amorphous intermediate compound containing these three component at about $1000^{\circ} \mathrm{C}$. A weak and broad IR absorption band of this compound was recognized between 950 to $1100 \mathrm{~cm}^{-1}$. As a result of formation of this intermediate product, the synthetic process of zircon was accelerated. Melting of this compound accelerates the reaction rate relating to the formation of zircon.

（日本化学会誌，1972，p.562 568）

\section{$N, N^{\prime}$ ジメチル-2,6-ピリジンジカルボンアミドを 配位した 2 価金属錯体}

(1971 年 11 月 8 日 受理)

野々山松雄・友本由 夫・山崎一雄*

$N, N^{\prime}$-ジチル-2,6-ビリシンジルボンフミド（以下 $\mathrm{mdpH}_{2}$ と略凐する）を配位した錯体は酸了ミド基およびビ リジン舆飞基つく赤外吸収スベクトルからつきの三つの型にわけられる。

$A$ 型： $\mathrm{MX}_{2}\left(\mathrm{mdpH}_{2}\right) \cdot n \mathrm{H}_{2} \mathrm{O}(\mathrm{M}=\mathrm{Co}, \mathrm{Ni}, \mathrm{Cu}, \mathrm{X}=\mathrm{Cl}, \mathrm{Br}), \mathrm{M}\left(\mathrm{mdpH}_{2}\right)_{2}\left(\mathrm{ClO}_{4}\right)_{2} \cdot 2 \mathrm{H}_{2} \mathrm{O}(\mathrm{M}=\mathrm{Ni}, \mathrm{Cu})$ 。 型 : $\mathrm{M}(\mathrm{NCS})_{2}\left(\mathrm{mdpH}_{2}\right)_{2} \cdot 4 \mathrm{H}_{2} \mathrm{O}(\mathrm{M}=\mathrm{Co}, \mathrm{Ni}), \mathrm{Co}\left(\mathrm{mdpH}_{2}\right)_{4}\left(\mathrm{ClO}_{4}\right)_{2} \cdot 10 \mathrm{H}_{2} \mathrm{O}_{0} \mathrm{C}$ 型 : $\mathrm{H}[\mathrm{MCl}(\mathrm{mdp})](\mathrm{M}=\mathrm{Pd}, \mathrm{Pt})_{0}$

$\mathrm{A}$ 型錯体中では $\mathrm{mdpH}_{2}$ はビリジン環の铚素と二つの酸了ミド基の酸莱とで配位している。これらのらちコハルト 錯体は八面体と四面体との錯イオン $\left[\mathrm{Co}\left(\mathrm{mdpH}_{2}\right)_{2}\right][\mathrm{CoX}]_{4} \cdot \mathrm{H}_{2} \mathrm{O}$ から構成されているが, 他の金属の錯体は八面体で ある。B型錯体中では $\mathrm{mdpH}_{2}$ は金属に配位せすと金属塩の格子中K取り込まれているにすきないが，加熱すると脱 水されてA 型錯体と同様になる。C型錯体では酸てミド基は水来を失って窒案で配位している。このC型錯体の構造 は塩化物イオンが配位した平面であり，白金およびパラジゥム以外の金属についてはC型錯体は単離できなかった。

\section{1 粕言}

酸アミド基は強い平面性1)と，また配位可能な原子として酸䋈 と跮素とをもっており，これが錯体中でどのように配位し，どの よ5な効果を中心金属炕与えるかる検討することは興味がある。 すでに 2-ピリジンカルボンアミドならびにその $N$-メチルおよび $N, N$-ジメ゙チル誘導体について研究したが299, 今回は, さらにる ラ一つの酸アミド基をピリジン環の 6-位にもち，三座配位子と なり得る 2,6-ピリジンジカルボン酸 (ジピコリン酸)のアミドを

* 名古屋大学理学部化学教室, 名古屋市千種区不老睢

1) G. Govil, J.Chem.Soc., A, 1970, 2464.

2) 閶崎正夫, 山渏一雄, 日化, 87, 1053(1966).

3) M. Nonoyama, K. Yamasaki, Inorg.Chim. Acta, 3, 585 (1969).
配位子とする錯体を研究しだ。最近，三座配位子である $2,2^{\prime}, 2^{\prime \prime}$ テルピリジンタ) 2-ビリジンカルバルデヒド-2'-ピリジルヒドラ ゾンの)なとが五配位錯体を与えることが報告されており，骨格の 類似した 2,6-ピリジンジカルボンフミドもまた五配位錯体を生 成することが期待される。目的とした2, 6-ピリジンジカルボンア ミド恃通常の溶媒にほとんど溶けず，錯体の合成に不便なため， 新化合物である $N, N^{\prime}$-ジメチル-2,6-ピリジンジカルボンアミド （以下 $\mathrm{mdpH}_{2}$ と略記する，図1) を用いた。ここでは $\mathrm{mdpH}_{2}$ を配位したコバルト（II）、ニッケル(II)，銅（II)，パラジウム

4) J.S. Judge, W.A. Baker, Jr,, Inorg. Chim. Acta, 1. 239(1967).

5) F.Lions, I. G. Dance, J.Lewis, J.Chem.Sor., A, 1967, 565 . 
Table 1 Elemental analyses of complexes and their colours

\begin{tabular}{|c|c|c|c|c|}
\hline Complex & Colour & $\begin{array}{c}M(\%) \\
\text { Found (Calcd.) }\end{array}$ & $\begin{array}{c}N(\%) \\
\text { Found (Calcd.) }\end{array}$ & $\begin{array}{c}\mathrm{H}_{2} \mathrm{O}(\%) \\
\text { Found (Calcd.) }\end{array}$ \\
\hline 1. $\mathrm{CoCl}_{2}\left(\mathrm{mdpH}_{2}\right) \cdot 1 / 2 \mathrm{H}_{2} \mathrm{O}$ & Blue & $17.36(17.64)$ & $12.51(12.66)$ & $2.85(2.70)$ \\
\hline 2. $\mathrm{CoBr}_{2}\left(\mathrm{mdpH}_{2}\right) \cdot 1 / 2 \mathrm{H}_{2} \mathrm{O}$ & Blue & $13.94(14.00)$ & $9.93(9.98)$ & $1.95(2.14)$ \\
\hline 3. $\mathrm{Co}(\mathrm{NCS})_{2}\left(\mathrm{mdpH}_{2}\right)_{2} \cdot 4 \mathrm{H}_{2} \mathrm{O}$ & Red & $9.30(9.30)$ & $17.49(17.69)$ & $11.56(11.38)$ \\
\hline 4. $\mathrm{Co}\left(\mathrm{mdpH}_{2}\right)_{4}\left(\mathrm{ClO}_{4}\right)_{2} \cdot 10 \mathrm{H}_{2} \mathrm{O}$ & Pink & $4.98(4.87)$ & 13. $98(13.88)$ & $14.44(14.88)$ \\
\hline 5. $\mathrm{NiCl}_{2}\left(\mathrm{mdpH}_{2}\right) \cdot \mathrm{H}_{2} \mathrm{O}$ & Yellow & $17.09(17.22)$ & $12.15(12.33)$ & $5.71(5.29)$ \\
\hline 6. $\mathrm{Ni}(\mathrm{NCS})_{2}\left(\mathrm{mdpH}_{2}\right)_{2} \cdot 4 \mathrm{H}_{2} \mathrm{O}$ & Blue & $9.10(9.26)$ & $17.59(17.70)$ & $11.37(11.38)$ \\
\hline 7. $\mathrm{Ni}(\mathrm{mdpH})_{2}\left(\mathrm{ClO}_{1}\right)_{2} \cdot 2 \mathrm{H}_{2} \mathrm{O}$ & Blue-green & $8.70(8.63)$ & $12.31(12.36)$ & $5.81(5.30)$ \\
\hline 8. $\mathrm{CuCl}_{2}\left(\mathrm{mdpH}_{2}\right)$ & Yellow-green & $19.08(19.39)$ & $12.51(12.81)$ & a) \\
\hline 9. $\mathrm{Cu}\left(\mathrm{mdpH}_{2}\right)_{2}\left(\mathrm{ClO}_{4}\right)_{2} \cdot 2 \mathrm{H}_{2} \mathrm{O}$ & Blue & $9.39(9.28)$ & - $12.39(12.27)$ & $5.38(5.27)$ \\
\hline 10. $\mathrm{H}[\mathrm{PdCl}(\mathrm{mdp})]$ & Yellow & $31.67(31.85)$ & $12.35(12.58)$ & b) \\
\hline 11. $\mathrm{H}[\mathrm{PtCl}(\mathrm{map})]$ & Yellow & $45.81(46.16)$ & $9.88(9.94)$ & c) \\
\hline a) $\mathrm{Cl}: 21.53(21.33) \%, b)$ & $67(10.61) \%, c)$ & $.47(25.58) \%$, & $45(2.38) \%$ & \\
\hline
\end{tabular}<smiles>CNC(=O)c1cccc(C(=O)N(C)[Tl])n1</smiles>

Fig. $1 N, N$-Dimethyl-2, 6-pyridinedicarboxamide

（II）呿よび白金（II）錯体を合成し，その性筫を調べた。

\section{2 実邪}

2.1 眍位子, $N, N^{\prime}$-ジメチル-2,6-ビリジンジカルボンアミド の合成

文献りにしたがって合成した 2,6 -ピリジンジカルボン酸ジェチ ルエステル（融点は文献值 $41 \sim 42^{\circ} \mathrm{C}$ と一致） $25 \mathrm{~g} を ， 30 \% の$ メチルフミンのエタノール溶液 $150 \mathrm{ml}$ K溶かし, 室温で数日放 置する。反応液を減王鋠縮すると白色の結晶が得られる。エタノ 一ルから再結晶する。取量 $16 \mathrm{~g}$ 。 $\mathrm{mp} 217 \sim 219^{\circ} \mathrm{C}$ 。

分析値 C $56.26 \%$ ，H $5.78 \% ， N 21.76 \%$

$\mathrm{C}_{7} \mathrm{H}_{11} \mathrm{~N}_{3} \mathrm{O}_{2}$ としての

評算值 C $55.94 \% ，$ H $5.75 \% ， N 21.75 \%$

$\mathrm{mdpD}_{2}$ （重水素化した配位子）は $\mathrm{mdpH}_{2}$ を重水から再結晶す ると得られる。

\section{2 錯体の合成（色および分析值は表 1 参照）}

ここで合成した錯体は，バラジウムと白金を除き，通常の有機 溶媒にはほとんど不溶であるが水には可溶である。しかし水溶液 は分解して，浀樎すると配立子の結晶が析出するため再結晶は困 難である。またパラジウムと白金との錯体はジメチルスルホキシ ト゚のみには可溶であるが，溶液を濃縮すると油状となり苒結晶は できなかった。

2.2.1 $\left.\mathrm{CoCl}_{2}\left(\mathrm{mdpH}_{2}\right) \cdot 1 / 2 \mathrm{H}_{2} \mathrm{O}^{7}\right), \quad \mathrm{CoBr}_{2}\left(\mathrm{mdpH}_{2}\right) \cdot 1 / 2 \mathrm{H}_{2} \mathrm{O}$, $\mathrm{NiCl}_{2}\left(\mathrm{mdpH}_{2}\right) \cdot \mathrm{H}_{2} \mathrm{O}:$ 塩化コバルト $1.4 \mathrm{~g}$ を 1-ブタノール 100 $\mathrm{ml}$ に溶かし，配位子 $1.0 \mathrm{~g}$ の l-ブタノール溶夜 $100 \mathrm{ml}$ と混合 し，濃縮すると青色の粉末として錯体が沈殷する。1-ブタノール で洗い風蔽する（収量 $0.5 \mathrm{~g}$ )。他の二錯体も同様に合成される。

2.2.2 $\mathrm{CuCl}_{2}\left(\mathrm{mdpH}_{2}\right)$ : 溶媒にエタノールを用いて, 2.2 .1 と 同様仙合成される。

6) R. A. Barnes, H.M. Fales, J. Amer. Chem.Soc., 75, 3830 (1953).

7) 名称はシクロロ(N, $N^{\prime}$ ーシメチル-2,6-ピりシンジカルボン フミド)コバルト(正)半水和物. 以下同様.
2.2.3 $\mathrm{Co}(\mathrm{NCS})_{2}\left(\mathrm{mdpH}_{2}\right)_{2} \cdot 4 \mathrm{H}_{2} \mathrm{O}, \quad \mathrm{Ni}(\mathrm{NCS})_{2}\left(\mathrm{mdpH}_{2}\right)_{2} \cdot 4$ $\mathrm{H}_{2} \mathrm{O}$ : チオシアン酸コバルト $1.0 \mathrm{~g}$ を水 $20 \mathrm{ml}$ に溶かし, 配位 子 $0.5 \mathrm{~g}$ の水溶液 $20 \mathrm{ml}$ と混合し, 室温で数日放置子ると赤色の 結晶が析出する。取量 $0.3 \mathrm{~g} 。$ ○ッル錯体す同様に合成される。 これらの錯体は $100^{\circ} \mathrm{C}$ て減仕乾燥すると完全に脱水され，空気 中で安定な無水の錯体, $\mathrm{Co}(\mathrm{NCS})_{2}\left(\mathrm{mdpH}_{2}\right)_{2}$ (青), $\mathrm{Ni}(\mathrm{NCS})_{2}$ ・ $\left(\mathrm{mdpH}_{2}\right)_{2}$ (緑) とになる。

2.2.4 $\mathrm{Ni}\left(\mathrm{mdpH}_{2}\right)_{2}\left(\mathrm{ClO}_{4}\right)_{2} \cdot 2 \mathrm{H}_{2} \mathrm{O}, \quad \mathrm{Cu}\left(\mathrm{mdpH}_{2}\right)_{2}\left(\mathrm{ClO}_{4}\right)_{2} \cdot 2$ $\mathrm{H}_{2} \mathrm{O}, \mathrm{Co}\left(\mathrm{mdpH}_{2}\right)_{4}\left(\mathrm{ClO}_{4}\right)_{2} \cdot 10 \mathrm{H}_{2} \mathrm{O}$ : 過㙁素酸銅 $3.0 \mathrm{~g}$ と配位子 $1.0 \mathrm{~g}$ とをそれぞれ $15 \mathrm{ml}$ の水に溶かして搌合，結晶が析出する まで加熱港縮する。取量 $1.5 \mathrm{~g}$ 。他のニッケル, コハルト錯体る 同様に合成される。

2.2.5 H[PdCl(mdp) $]^{8)}, \mathrm{H}[\mathrm{PtCl}(\mathrm{mdp})]: \mathrm{K}_{2} \mathrm{PtCl}_{4} 1.0 \mathrm{~g}$ を 熱水 $20 \mathrm{ml}$ k溶かし, 配位子 $0.5 \mathrm{~g}$ の熱水溶液 $20 \mathrm{ml}$ と濐合し,

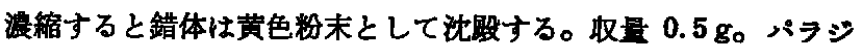
ウム錯体す同様に合成される。

2.2.6 面水素化した錯体：溶媒に重水また㤬重エタノールを 用い通常の錯体と同様结合成した。

\section{3 测 宽}

すでに報告した方法”と同じであるが，核磁気共鳴スベクトル は日本電子 $\mathrm{C}-60 \mathrm{H}$ 型分光器を用いて, TMS を内部標準として $23.5^{\circ} \mathrm{C}$ で測定した。

\section{3. 結县}

新しく合成した $N, N^{\prime}$-ジメテル-2,6-ピリジンジカルボンアミ ト ( $\left.\mathrm{mdpH}_{2}\right)$ は，元素分析を行ない，赤外吸収および核磁気共鸧 スベクトルでつぎのよらに確譐した。すなわち、赤外吸収スベク トル（表 2）は2級の酸つミド基に特有の吸收带を示し，その禗 属は重水素化化より確かめた9。。固体ではアミド】の服収が 2 本 に分裂しているが，重クロロホルム溶液では分裂はみらられず 1672 $\mathrm{cm}^{-1}$ に 1 本現われるのみであるから，その分裂は結晶状態での 水素結合などによると思われる。核硳気共䳛スベクトルでは， $\delta=2.93 \mathrm{ppm}$ に二重線 $(6 \mathrm{H}), \delta=9.01 \mathrm{ppm}$ に蜼広、四重線 $(2 \mathrm{H})$ がみられ，前者は睴アミド基の窒素に結合しているメキル基に， 後者はその水素淿属され10)，両者は $J=4.7 \mathrm{~Hz}$ でカップリンダ している。ピリジン環の水秦は $\delta=7.8-8.5 \mathrm{ppm}$ (3 H) 飞 $\mathrm{AB}_{2}$

8) 名称はクロロ $\left(N, N^{\prime}\right.$-ジメテル-2,6-ピリシンンジルポンフ ミダト)バラジウム(II)酸. 白金錯体す同棣.

9）野々山松雄，北川章子，山崎一雄，日化，92，839(1971). 
Table 2 Infrared spectral bands of acid amide groups $\left(\mathrm{cm}^{-1}\right)$

\begin{tabular}{|c|c|c|c|c|c|}
\hline \multirow{2}{*}{ Compound } & \multirow{2}{*}{$\nu_{\mathrm{N}-\mathrm{H}}$} & \multicolumn{3}{|c|}{ Amide } & \multirow{2}{*}{$\pi_{\mathrm{C}=0}$} \\
\hline & & $\mathrm{I}$ & II & III & \\
\hline $\mathrm{mdpH}_{2}$ & 3310 & $\begin{array}{l}1657 \\
1683\end{array}$ & $\begin{array}{l}1528 \\
1546\end{array}$ & 1246 & 442 \\
\hline $\mathrm{mdpD}$ & 2470 & $\begin{array}{l}1650 \\
1680\end{array}$ & 1471 & 947 & 435 \\
\hline \multicolumn{6}{|l|}{ Type A complex } \\
\hline 8. $\mathrm{CuCl}_{2}\left(\mathrm{mdpH}_{2}\right)$ & 3250 & 1638 & 1552 & 1345 & 492 \\
\hline $8 \mathrm{D} . \mathrm{CaCl}_{2}\left(\mathrm{mdpD} \mathrm{D}_{2}\right)$ & 2407 & 1636 & 1481 & 948 & 481 \\
\hline $\begin{array}{l}\left.\text { 7. } \mathrm{Ni}(\mathrm{mdpH})_{2}\right)_{2}\left(\mathrm{ClO}_{4}\right)_{2} \cdot 2 \mathrm{H}_{2} \mathrm{O} \\
\text { Type B complex }\end{array}$ & 3310 & 1642 & 1548 & 1345 & 493 \\
\hline 3. $\mathrm{Co}(\mathrm{NCS})_{2}\left(\mathrm{mdpH}_{2}\right)_{2} \cdot 4 \mathrm{H}_{2} \mathrm{O}$ & a) & $\begin{array}{l}1645 \\
1667\end{array}$ & $\begin{array}{l}1542 \\
1549\end{array}$ & 1240 & 447 \\
\hline 3 D. $\mathrm{Co}(\mathrm{NCS})_{2}\left(\mathrm{mdpD}_{2}\right)_{2} \cdot 4 \mathrm{D}_{2} \mathrm{O}$ & a) & $\begin{array}{l}1641 \\
1658\end{array}$ & 1487 & 926 & 443 \\
\hline 4. $\mathrm{Co}\left(\mathrm{mdpH}_{2}\right)_{4}\left(\mathrm{ClO}_{4}\right)_{2} \cdot 10 \mathrm{H}_{2} \mathrm{O}$ & $\begin{array}{l}3360 \\
3260\end{array}$ & $\begin{array}{l}1640 \text { sh } \\
1663\end{array}$ & 1540 & 1248 & 452 \\
\hline $4 \mathrm{D} . \mathrm{Co}\left(\mathrm{mdpD}_{2}\right)_{4}\left(\mathrm{ClO}_{4}\right)_{2} \cdot 10 \mathrm{D}_{2} \mathrm{O}$ & $\begin{array}{l}2420 \\
2460\end{array}$ & $\begin{array}{l}1642 \\
1658\end{array}$ & 1495 & 949 & 448 \\
\hline \multicolumn{6}{|l|}{ Anhydride of the type B complex } \\
\hline $3^{\prime} \cdot \mathrm{Co}(\mathrm{NCS})_{2}\left(\mathrm{mdpH}_{2}\right)_{2}$ & 3280 & $\begin{array}{l}1637 \\
1657\end{array}$ & $\begin{array}{l}1539 \\
1546\end{array}$ & $\begin{array}{l}1241 \\
1347\end{array}$ & $\begin{array}{l}485 \\
447\end{array}$ \\
\hline $3 \mathrm{D}^{\prime} \cdot \mathrm{Co}(\mathrm{NCS})_{2}\left(\mathrm{mdpD}_{2}\right)_{2}$ & $\begin{array}{l}2420 \\
2465\end{array}$ & $\begin{array}{l}1637 \\
1656 \mathrm{sh}\end{array}$ & $\begin{array}{l}1489 \\
1494 \mathrm{sh}\end{array}$ & $\begin{array}{l}945 \\
938\end{array}$ & $\begin{array}{l}443 \\
479\end{array}$ \\
\hline $4^{\prime} . \mathrm{Co}\left(\mathrm{mdpH}_{2}\right)_{4}\left(\mathrm{ClO}_{4}\right)_{2}$ & $\begin{array}{l}3360 \\
3300 \mathrm{sh}\end{array}$ & $\begin{array}{l}1639 \\
1665 \mathrm{sh}\end{array}$ & 1541 & $\begin{array}{l}1243 \\
1345\end{array}$ & $\begin{array}{l}460 \mathrm{sh} \\
491\end{array}$ \\
\hline $4 \mathrm{D}^{\prime} . \mathrm{Co}\left(\mathrm{mdpD}_{2}\right)_{4}\left(\mathrm{ClO}_{4}\right)_{2}$ & $\begin{array}{l}2425 \\
2470\end{array}$ & $\begin{array}{l}1639 \\
1660\end{array}$ & 1486 & 940 & b) \\
\hline
\end{tabular}

a) The $\mathrm{N}-\mathrm{H}$ band was obscured by the bands of $\mathrm{H}_{2} \mathrm{O}$ or $\mathrm{D}_{2} \mathrm{O}$. sh=shoulder. b) No carbonyl band was observed.

型のスペクトルを示す10)。したがってここに合成された配位子は 目的とした棈造をるっている。

ヌバルト、ニッケル，および銅の錯体は，金属塩が過剩の状態 でのみ合成され，その逆の条件では配位子の結晶がさきに析出 し、錯体は得られない。さらに，これらの鏙体の水溶液の吸収ス ベクトルはいずれすアコイオンとほとんど同じで，水溶液中では 配位子がかなり解離していると思われる。また 2-ピ日ジンカル ボンアミドのよらな酸アミド基の窐素が配位した錯体 ${ }^{2)}$ は単離で きなかった。錯体の水溶液に水酸化ナトリウムを加えると, コバ ルトは水酸化物を沈殿するのみであるが、ニッヶルは黄色に，銅 は深青色になり，酸アミド基が窒案で配位した錯体が生じたと思 われるが2)3，不安定で 2,3 日で分解する。このように $\mathrm{mdpH}_{2}$ は 三座配位子炕すかかわらず，その配位能力は 2-ピリジンカルボ ンアミドよりも弱い。これはその部分的偪固定された骨格のた め，三座で配位するには相当のひずみが生じるためであろら。パ ラジウムと白金は，コバト、ニッケル，銅とは異なり，酸てミ ド基の水索が解離した錯体を生成する。

\section{1 赤外吸収スベクトル}

錯体は岩塩領域の赤外吸収スペクトルから三つの型にわけられ

る(表 2 )。

$A$ 型: $\mathrm{MX}_{2}\left(\mathrm{mdpH}_{2}\right) \cdot n \mathrm{H}_{2} \mathrm{O}(\mathrm{X}=\mathrm{Cl}, \mathrm{Br} ; \mathrm{M}=\mathrm{Co}, \mathrm{Ni}, \mathrm{Cu})$, $\mathrm{M}\left(\mathrm{mdpH}_{2}\right)_{2}\left(\mathrm{ClO}_{4}\right)_{2} \cdot 2 \mathrm{H}_{2} \mathrm{O}(\dot{\mathrm{M}}=\mathrm{Cu}, \mathrm{Ni})$

B 型: $\mathrm{M}(\mathrm{NCS})_{2}\left(\mathrm{mdpH}_{2}\right)_{2} \cdot 4 \mathrm{H}_{2} \mathrm{O}(\mathrm{M}=\mathrm{Co}, \mathrm{Ni}), \mathrm{Co}\left(\mathrm{mdpH}_{2}\right)_{4}$. $\left(\mathrm{ClO}_{4}\right)_{2} \cdot 10 \mathrm{H}_{2} \mathrm{O}$

$\mathrm{C}$ 型: $\mathrm{H}[\mathrm{MCl}(\mathrm{mdp})](\mathrm{M}=\mathrm{Pt}, \mathrm{Pd})$

10) L. M. Jackman, S. Sternhell, "Application of Nuclear Magnetic Resonance Spectroscopy in Organic Chemistry", Pergamon, Oxford(1969)p.130, 215.
A型は酸アミド基の吸収带を, 約 1640 ( (アミドII), 約 $1340 \mathrm{~cm}^{-1}$ (アミドIII) に示し, $\mathrm{mdpH}_{2}$ の吸収帯 (平均值) と比較すると，アミドI住約 $30 \mathrm{~cm}^{-1}$ 低波数側に，

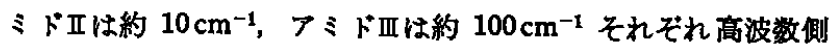
へ移動しており，この变化は酸つミド基がその酸素で梩位したこ とを示しているか。さらにこれらの錯体では眍位子にない，配位 したピリジン環に基づくと思われる強い吸収が約 $895 \mathrm{~cm}^{-1}$ に観 測される。また脱水してすスペクトルは影著な变化を示さない。

B型の錯体ではアミドIは約 1640 と 1665 飞, アミドIIは約 1540 K, アミド且は約 $1245 \mathrm{~cm}^{-1}$ に現われ，とくにアミド血は 配位子自身の位面に非常に近い。A型に見られた $895 \mathrm{~cm}^{-1}$ の吸 収はない。 B 型の錯体は $100^{\circ} \mathrm{C}$ で減圧脱水するとスペクトルが大 きく変化する。すなわち, アミド吕の吸収性約 1245 と $1340 \mathrm{~cm}^{-1}$ に分裂し，強い吸収が $895 \mathrm{~cm}^{-1}$ に新しく現われ，アミドIが分 裂した 2 本の吸取の相対強度が逆転する。すなわちスペクトル全 体は，A型とB型とを重ね合わせたるのとなり（表 2)，脱水に ともなって眍位子の一部が A 型錯体におけると同様の配位状熊に 変化したことを示している。

A 型と B 型との差は道赤外領域のスペクトルにおいてす顕著で ある。すなわち $\mathrm{mdpH}_{2}$ のピリジン環の $648 \mathrm{~cm}^{-1}$ の亲角振動は, A型では 675〜 $680 \mathrm{~cm}^{-1}$ に移動し,ピリジン環が配位しているこ とが示される $\mathrm{cm}^{-1}$ に钼測され，ピリジン環が配位していないことがわかる。 さらに $\mathrm{mdpH}_{2}$ の酸アミド基の $442 \mathrm{~cm}^{-1}$ の $\mathrm{CO}$ の面外変角振動 は、A型では 480〜498 $\mathrm{cm}^{-1}$ に移動するが、 B型では 440〜452 $\mathrm{cm}^{-1}$ K現われる。したがって，酸てミド基はA型ではその酸素

11) R. J. H. Clark, C. S. Williams, Inorg. Chem., 4, 350 (1965). 
Table 3 Infrared spectral bands of thiocyanato groups $\left(\mathrm{cm}^{-1}\right)$

\begin{tabular}{|c|c|c|c|}
\hline Complex & $\nu_{C=N}$ & $\delta_{\mathrm{NCS}}$ & $\nu_{M-N C S}$ \\
\hline 3. $\mathrm{Co}(\mathrm{NCS})_{2}\left(\mathrm{mdpH}_{2}\right)_{2} \cdot 4 \mathrm{H}_{2} \mathrm{O}$ & $\begin{array}{l}2120 \mathrm{~s} \\
2075 \mathrm{sh}\end{array}$ & $469 \mathrm{~m}$ & $236 \mathrm{br}, \mathrm{s}$ \\
\hline $3^{\prime} \cdot \mathrm{Co}(\mathrm{NCS})_{2}\left(\mathrm{mdpH}_{2}\right)_{2}$ & $2078 \mathrm{br}, \mathrm{s}$ & $479 \mathrm{~m}$ & $307 \mathrm{br}, \mathrm{s}$ \\
\hline 3D. $\mathrm{Co}(\mathrm{NCS})_{2}\left(\mathrm{mdpD}_{2}\right)_{2} \cdot 4 \mathrm{D}_{2} \mathrm{O}$ & $\begin{array}{l}2120 \mathrm{~s} \\
2075 \mathrm{sh}\end{array}$ & $470 \mathrm{~m}$ & $235 \mathrm{br}, \mathrm{m}$ \\
\hline $3 \mathrm{D}^{\prime} \cdot \mathrm{Co}(\mathrm{NCS})_{2}(\mathrm{mdphD})_{2}$ & $2078 \mathrm{br}, \mathrm{s}$ & $479 \mathrm{~m}$ & $306 \mathrm{br}, \mathrm{s}$ \\
\hline 6. $\mathrm{Ni}(\mathrm{NCS})_{2}\left(\mathrm{mdpH}_{2}\right)_{2} \cdot 4 \mathrm{H}_{2} \mathrm{O}$ & $\begin{array}{l}2135 \mathrm{~s} \\
2090 \mathrm{sh}\end{array}$ & $469 \mathrm{~m}$ & $250 \mathrm{~s}$ \\
\hline $\begin{array}{l}6^{\prime} . \mathrm{Ni}(\mathrm{NCS})_{2}\left(\mathrm{mdpH}_{2}\right)_{2} \\
\mathrm{~s}=\text { strong, } \mathrm{sh}=\text { shoulder, }\end{array}$ & $\begin{aligned} & 2108 \mathrm{br}, \mathrm{s} \\
= & \text { medium, } \mathrm{b}\end{aligned}$ & $476 \mathrm{~m}$ & $240 \mathrm{br}, \mathrm{s}$ \\
\hline
\end{tabular}

で配位しているが3，B型では配位に関与していない。また B 型 錯体は脱水することにより，A型とB型とを重社合わせたスペク トルを示すよらになる。これらの結果は岩塩領域の結果と完全に 一致する。

C 型では酸アミド基の $\boldsymbol{N}_{\mathrm{N}-\mathrm{H}}$ が消失し，その水素が失われてい ることが示され，また $\nu_{\mathrm{C}=0}$ が $1548 \mathrm{~K}, \nu_{\mathrm{C}-\mathrm{N}}$ が $1401 \mathrm{~cm}^{-1}$ K 現われ，酸アミド基は窒素で配位していることがわかるす。っの 注か $1200 \sim 450 \mathrm{~cm}^{-1}$ にわたって非常に幅広い吸収が存在してい る。

チオシフナト錯体の ע עC-8 は配位子の吸収と重なり帰属できない（表 3)。無水のコン゙

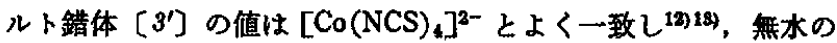
ニッヶル錆体 $\left[6^{\prime}\right]$ の值も，八面体ポリマーの $\left[\mathrm{Ni}(\mathrm{NCS})_{4}\right]^{2-}$ と ほぼ一致する ${ }^{12) 18) 。 ~}$

コン゙ルトのクロロ[1]およびブロモ錯体［2]は298およ゙ $231 \mathrm{~cm}^{-1} k \nu_{\mathrm{Co}-\mathrm{x}}$ 飞㷌属される強い㖟收を示し， $\left[\mathrm{CoCl}_{4}\right]^{2-}$ お。 よび $\left[\mathrm{CoBr}_{4}\right]^{2-}$ が存在することがかかる14)。しかしこの吸収は五 配位錯体の $\nu_{\mathrm{Co}-\mathrm{x}}$ とは一致しない(16)。またニッケルのク口ロ錯 体〔5]恃 $\nu_{\mathrm{N} 1-\mathrm{Cl}}$ を $242 \mathrm{~cm}^{-1}$ に示し, 六配位であることがわ かる10)。パラジウム [10] と白金錯体 [11] の $\nu_{\mathrm{M}-\mathrm{Cl}}$ はそれぞれ 291 と $294 \mathrm{~cm}^{-1}$ とにある。

\section{2 碳 化}

パシジウムと白金錯体は反磁性であり，他の錯体の磁気モーメ
ントを表4に示した。コバルトのクロロ[1]，ブロモ[2]およ び無水のチオシアナト鑤体 [ $\left.3^{\prime}\right]$ の值恃四面体 (4.2 4.8 B.M.) と八面体（4.7〜5.2 B.M.）のほ注境界の值であるが，他仙いず れる八面体錯体の犆である ${ }^{17)}$ 。

\section{3 㹡敕反讨スベクトル}

コバルトのクロロ[1]およびブロモ鉷体［2] は四面体型の， チオシアナト錯体 [3]打上び過塩素酸塩 [4] 恃八面体型錯体 のスペクトルを与える（表 4, 図 2) ${ }^{18)}$ 。をたチオシフナト錯体 〔3]岋脱水すると赤色から青色化変化し，スペ》トルは八面体 型から四面体型へと変化する（図 2)。ニッケル錯体はすべて分 面体型のスペクトルを示し ${ }^{28)}$, 吸收極大仕低波数側から， ${ }^{9} A_{20} \rightarrow$ ${ }^{8} T_{2 g}\left(\nu_{1}\right),{ }^{8} A_{2 g} \rightarrow{ }^{3} T_{1 g}(\mathrm{~F})\left(\nu_{2}\right),{ }^{8} A_{2 g} \rightarrow{ }^{8} T_{1 g}(\mathrm{P})\left(\nu_{8}\right)$ と淿属される。

Wave length $(\mathrm{m} \mu)$

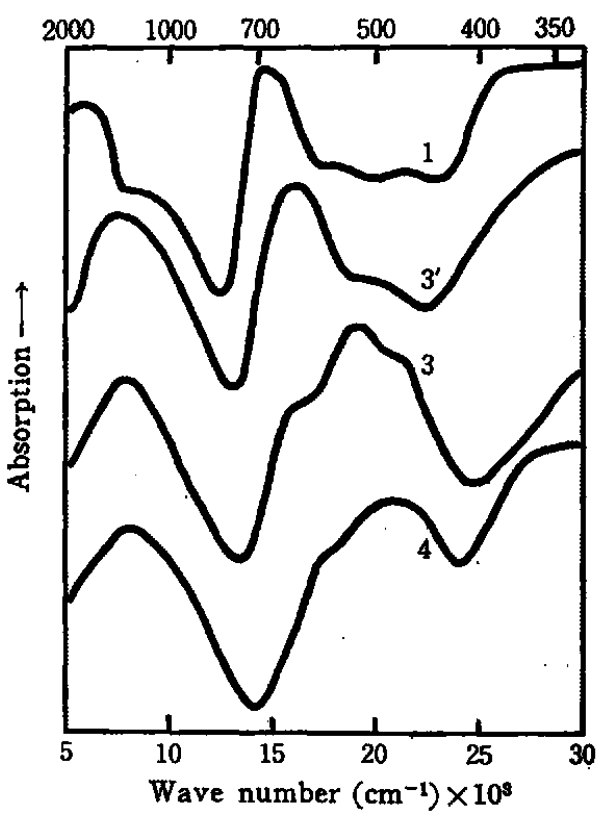

Fig. 2 Diffuse reflectance spectra

$1: \mathrm{CoCl}_{2}\left(\mathrm{mdpH}_{2}\right) \cdot 1 / 2 \mathrm{H}_{2} \mathrm{O}, 3: \mathrm{Co}(\mathrm{NCS})_{2}\left(\mathrm{mdpH}_{2}\right)_{2} \cdot 4 \mathrm{H}_{2} \mathrm{O}$ $3^{\prime}: \mathrm{Co}(\mathrm{NCS})_{2}\left(\mathrm{mdpH}_{2}\right)_{2}, 4: \mathrm{Co}\left(\mathrm{mdpH}_{2}\right)_{4}\left(\mathrm{ClO}_{4}\right)_{2} \cdot 10 \mathrm{H}_{2} \mathrm{O}$

Table 4 Magnetic moments and diffuse reflectance spectra

Complex

1. $\mathrm{CoCl}_{2}\left(\mathrm{mdpH}_{2}\right) \cdot 1 / 2 \mathrm{H}_{2} \mathrm{O}$

2. $\mathrm{CoBr}_{2}\left(\mathrm{mdpH}_{2}\right) \cdot 1 / 2 \mathrm{H}_{2} \mathrm{O}$

3. $\mathrm{Co}(\mathrm{NCS})_{2}\left(\mathrm{mdpH}_{2}\right)_{2} \cdot 4 \mathrm{H}_{2} \mathrm{O}$

$3^{\prime}$. $\mathrm{Co}(\mathrm{NCS})_{2}\left(\mathrm{mdpH}_{2}\right)_{2}$

4. $\mathrm{Co}\left(\mathrm{mdpH}_{2}\right)_{4}\left(\mathrm{ClO}_{4}\right)_{2} \cdot 10 \mathrm{H}_{2} \mathrm{O}$

5. $\mathrm{NiCl}_{2}\left(\mathrm{mdpH}_{2}\right) \cdot \mathrm{H}_{2} \mathrm{O}$

6. $\mathrm{Ni}(\mathrm{NCS})_{2}\left(\mathrm{mdpH}_{2}\right)_{2} \cdot 4 \mathrm{H}_{2} \mathrm{O}$

6'. $\mathrm{Ni}(\mathrm{NCS})_{2}\left(\mathrm{mdpH}_{2}\right)_{2}$

7. $\mathrm{Ni}\left(\mathrm{mdpH}_{2}\right)_{2}\left(\mathrm{ClO}_{4}\right)_{2} \cdot 2 \mathrm{H}_{2} \mathrm{O}$

8. $\mathrm{CuCl}\left(\mathrm{mdpH}_{2}\right)$

9. $\mathrm{Cu}\left(\mathrm{mdpH}_{2}\right)_{2}\left(\mathrm{ClO}_{4}\right)_{2} \cdot 2 \mathrm{H}_{2} \mathrm{O}$

$\mathrm{w}=$ weak, $\mathrm{sh}=$ shoulder, $\mathrm{br}=\mathrm{broad}$

12) D. Forster, D.M.L. Goodgame, Inorg. Chem., 4, 823 (1965).

13) D. Forster, D. M. L. Goodgame, ibid., 4, 715(1965).

14) A. Sabatini, L. Sacconi, J. Amer. Chem, Soc., 86, 17 (1964).
Diffuse reflectance spectrum $\left(\mathrm{cm}^{-1}\right) \times 10^{3}$

$5.7,8.7 \mathrm{w}, 15.0,18.5 \mathrm{sh}, 21.6 \mathrm{w}$

$4.8,7.5 \mathrm{sh}, 9.9 \mathrm{w}, 14.0,17.0 \mathrm{w}, 18.9 \mathrm{sh}, 21.0 \mathrm{w}$

$7.8,15.8 \mathrm{sh}, 19.0,21.0 \mathrm{sh}$

$7.6,16.1,20.5 \mathrm{sh}$

$8,1,17: 5$ sh, 20.9

$7.8,12.3,13.5 \mathrm{sh}, 18.5 \mathrm{sh}, 23.0$

$8.9,14.5 \mathrm{br}, 21.0 \mathrm{sh}, 25.8 \mathrm{br}$

8. $0 \mathrm{sh}, 9.1,15.3,24.0 \mathrm{sh}$

$7.0 \mathrm{sh}, 9.8,11.5 \mathrm{sh}, 15.8,17.0 \mathrm{sh}, 25.0 \mathrm{sh}$

$10.0 \mathrm{br}, 24.5 \mathrm{sh}$

$6.7,12.3$

15) D. Bryson, .R.H. Nuttall, Spectrochim. Acta, 26 A, 2275 (1970).

16) C. Postmus, J.R. Ferraro, A. Quattrochi, K. Shobatake, K. Nakamoto, Inorg. Chem., 8, 1851(1969).

17) E.K. Barefield, D.H.Busch, S.M.Nelson, Quart. Rev., 22, 457 (1969). 


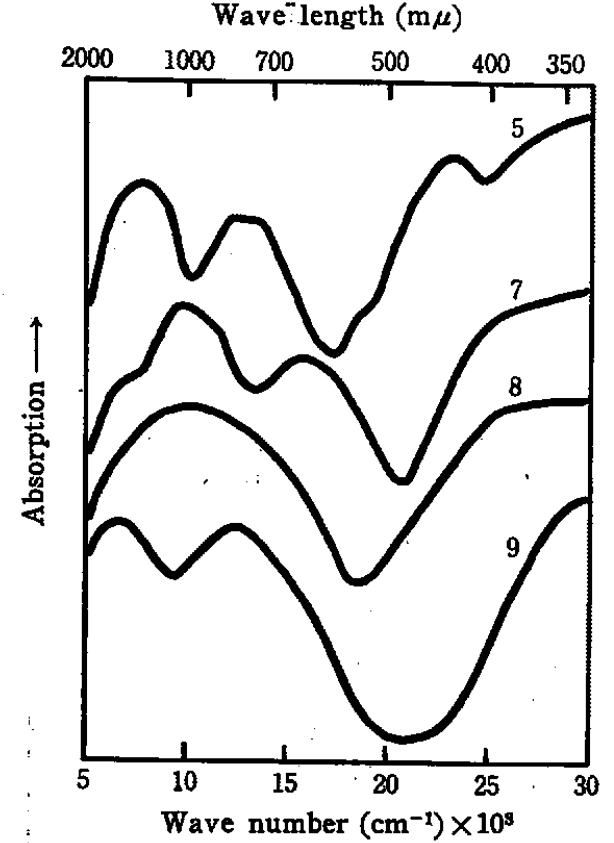

Fig. 3 Diffuse reflectance spectra

$5: \mathrm{NiCl}_{2}\left(\mathrm{mdpH}_{2}\right) \cdot \mathrm{H}_{2} \mathrm{O}, 7: \mathrm{Ni}\left(\mathrm{mdpH}_{2}\right)_{2}\left(\mathrm{ClO}_{4}\right)_{2} \cdot 2 \mathrm{H}_{2} \mathrm{O}$

$8: \mathrm{CuCl}_{2}(\operatorname{mdpH})_{2}, 9: \mathrm{Cu}\left(\mathrm{mdpH}_{2}\right)_{2}\left(\mathrm{ClO}_{4}\right)_{2} \cdot 2 \mathrm{H}_{2} \mathrm{O}$

シックルのチオシアナト錯体 [6] はコゴルトと同様, 脱水にと あなって変化するが，それ注と頑著ではなく、スペクトルはいず

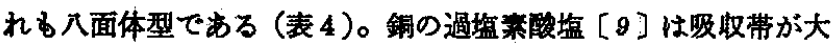
きく分裂している（図3）。”

\section{4 考察}

\section{1 過塩素酸塩稓体}

ニッケル錯体〔r]の構造注，拡散反射スペクトルから八面体 と考えられる（図 4 A)。ここでは，ビリジン理と二つの酸アミ ド基とをすった $\mathrm{mdpH}_{2}$ のめる程度固定された骨格のため, 配位 厘子は同一平面内にのみ，すなわち mer 型にしか安定に配位で きないと思かれる（図 4)。さらに $\nu_{1}$ の值から $D q=980 \mathrm{~cm}^{-1}$ と なり， $\mathrm{mdpH}_{2}$ の配位子場は $N-$ メチル-2-ビリジンカルボンアミ F (mepiaH) $D q=1010 \mathrm{~cm}^{-1}$ より少し弱い。錯体 [7]の配 位原子は酸丁ミド基の酸素 4 個とピリジン環の空素 2 個であるの K対し, [Ni(mepiaH)s] $]^{2+}$ では酸素 3 個と窒素 3 個である。これ

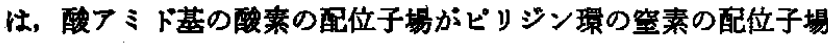
よりも弱いことを示している。

銅錯体〔9]では，d-d 吸収帯が顕著飞分裂しているが，その

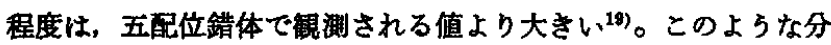

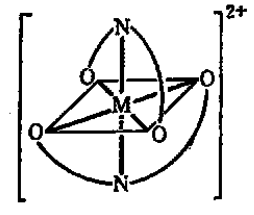

A [M(mdpH $\left.\mathrm{M}_{2}\right]_{2}^{2+}$. $\left(\mathrm{MCl}_{2}\left(\mathrm{mdpH} \mathrm{H}_{2}\right) \mathrm{I}_{2}\right.$

Fig. 4 Proposed structures

18) A. B. P. Lever, "Inorganic Electronic Spectroscopy", Elsevier, Amsterdam(1968)p. 318, 333.

19) E.D.McKenzie, J.Chem.Soc., A, 1970, 3095.
裂はテトラゴナルにひずんだ八面体に基つくくすのと考えられてお

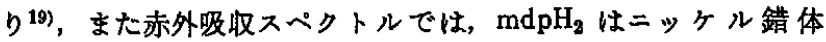
[7]と同様に配位していることが示されているから、ニッヶル 錯体 [7]と類似の構造であると思われる（図 4 A)。

コン゙ルト錯体〔4]は上記のニッケルおよび鋼鍺体〔7〕、〔9] とはまったく異なった組成と赤外吸収スペクトル（B型）とを示 す。錯体 $[7]$ と $[9]$ では酸アミド基性酸素で配位していたが， [4]では赤外㖟取スペクトルの結果から酸アミド基は配位して いないるのと結論される。また，2,6-ジメチルピリジンがその立 体障害により配位しにくいことを考えると ${ }^{20)}$, 酸アミド基が配位 せずに，ピリジン環の窒素のみが配位することは困難であろう。 さらに赤外吸取スペクトルもピリジン環が配位していないことを 示す。また，[4]の拡散反射スペクトル（図2）がアコ錯体のス ペクトルとほぼ一致する ${ }^{18)}$ 。したがってこの錯体は, $\left[\mathrm{Co}\left(\mathrm{H}_{2} \mathrm{O}\right)_{6}\right]$. $\left(\mathrm{ClO}_{4}\right)_{2} .4 \mathrm{H}_{2} \mathrm{O} .4 \mathrm{mdpH}_{2}$ と書くべきであり、ピリジンおよびその 誘導体が中心金属に配位せずに，結晶中に取り込まれている場合 飞対応する ${ }^{21) 。 ~}$

\section{2 チオシアナト難体}

コパルトおよびニッケル錯体［3］，［6］ともに八面体の性質 を示すが，赤外吸収スペクトルから，コハルト過塩素酸塩〔4] の場合と同様, $\mathrm{mdpH}_{2}$ は配位していないと思われる。このこと は，二ッケル錯体 [6] の反射スペクトルが，錯体 [7]と異な っていることと矛盾しない。しかし、チオシアン酸イオンはその

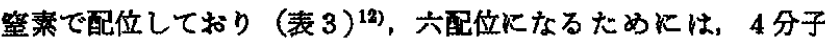
の水が配位する必要がある。たとえば，塩化ニッケルおよび塩化 コバルト六水和物はいずれすtrans $-\left[\mathrm{MCl}_{2}\left(\mathrm{H}_{2} \mathrm{O}\right)_{4}\right] \cdot 2 \mathrm{H}_{2} \mathrm{O}$ であ ることが知られており ${ }^{22)}$, 多分この場合も類似の槽造 trans$\left[\mathrm{M}(\mathrm{NCS})_{2}\left(\mathrm{H}_{2} \mathrm{O}\right)_{4}\right] \cdot 2 \mathrm{mdpH}_{2}$ であろ5。

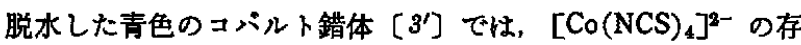
在が赤外吸収括よび抾散反射スペクトルならびに磁化率から示さ れる一方，酸了ミド基怙よびピリジン環の赤外吸取スペクトルか ら，配位した $\mathrm{mdpH}_{2}$ と，配位していない $\mathrm{mdpH}_{2}$ とがともに存 在することがわかる。したがって脱水によってつぎの変化が起こ ると考えられる。

$2\left[\mathrm{Co}(\mathrm{NCS})_{2}\left(\mathrm{H}_{2} \mathrm{O}\right)_{4}\right] \cdot 2 \mathrm{mdpH}_{2}$

$\longrightarrow\left[\mathrm{Co}\left(\mathrm{mdpH}_{2}\right)_{2}\right]\left[\mathrm{Co}(\mathrm{NCS})_{4}\right] \cdot 2 \mathrm{mdpH}_{2}+8 \mathrm{H}_{2} \mathrm{O}$

しかし拡散反射スペクトルにおいて， $\left[\mathrm{Co}\left(\mathrm{mdpH}_{2}\right)_{2}\right]^{2+}$ の存在す ることが琶められないのは，そのスペクトルの強度が四面体の錯 陰イオンの数十分の一以下であるためと思われる28)

ニッケル錯体 $[6]$ あ上式にしたがって, コバルト錯体 [3]と 同じ変化をする。その生物中の錯陽イオンはコバルトの場合と同 じ構造であるが，[Ni(NCS)、 $]^{2-}$ は、すで知られているよらに 八面体のポリマーであろ ${ }^{12)}$ 。したがって，払散反射スペクトル がかなり幅広くなっているのは，錯陽イオンと鍇陰イオンのスペ クトルが重なったためと考えられる。

この二つのチオシアナト錯体は，合成されたときは $\mathrm{mdpH}_{2}$ が

20) D. J.Machin, J.F.Sullivan, J.Chem. Soc., A, 1971, 658.

21) D.W. Herlocker, M. R. Rosenthal, Inorg. Chim. Acta, 4, 501(1970).

22) C. J. Ballhausen, "Introduction to Ligand Field Theory", McGraw-Hill, New York(1962)p. 255, 261.

23）文献 17) の p.131, 
結晶格子の中にとりこまれ，見かけ上の結晶水が配位した構造で あるが，脱水により不均一化反応を起こし， $\mathrm{mdpH}_{2}$ の一部が配 位した錯体 $\left[\mathrm{M}\left(\mathrm{mdpH}_{2}\right)_{2}\right] \cdot\left[\mathrm{M}(\mathrm{NCS})_{4}\right] \cdot 2 \mathrm{mdpH}_{2}$ となる。

\section{3 クロロおよびブロ錯体}

ニッケル錯体 [5]の拻散反射スペクトルは，上に述べた錯体 〔7]と比較すると呧波数側へ移動し, ニッケルのまわりの配位 子場が弱いことが示され $\left(\nu_{1}=10 D q=7800 \mathrm{~cm}^{-1}\right)$ ，配位子場の 弱い塩化物イオンが配位していることが示される（図 $4 \mathrm{~B}$ )。し かし，六配位ニッケル鉷体に特ける橋かけしたニッケルー塩素結 合に基つく $\nu_{\mathrm{N} i-\mathrm{Cl}}$ は，一般に $200 \mathrm{~cm}^{-1}$ 以下に現われるため ${ }^{16)}$, 剆定できなかったが，末端の $\nu_{\mathrm{N} 1-\mathrm{Cl}}$ は $242 \mathrm{~cm}^{-1}$ に認められた。 銅錯体〔8]の赫外吸収スペクトルは $400 \mathrm{~cm}^{-1}$ まではニッヶ ル錯体 [5]とほとんど同じであるが，それ以下は舆なって括り，

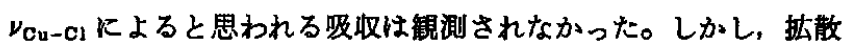
反射スペクトルの愊広い $d-d$ 吸収帯はかなり低波数にあるため， ニッケルの場合と同様、塩化物イオンが配位していると思われ る。このことは近紫外部に錯体 [9]kはない銅-塩菜間の電荷移

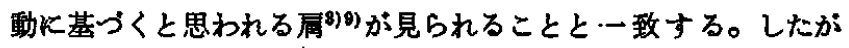
って図 4 B の棈造が推定される。

コバルト錯体 [1]和よび［2]に执いては，胁散反射および 速赤外吸収スペクトルから $\left[\mathrm{CoX}_{4}\right]^{2-}$ の存在することが示され, $\mathrm{mdpH}_{2}$ は酸アミド基の酸案とピリジン環の窒菜で跑位しており， 磁化率は八面体型と四面体型との中間であった。したがって本錯 体は $\left[\mathrm{Co}\left(\mathrm{mdpH}_{2}\right)_{2}\right]\left[\mathrm{CoX} 4 \cdot \mathrm{H}_{2} \mathrm{O}\right.$ と書くべきである。倣反射ス

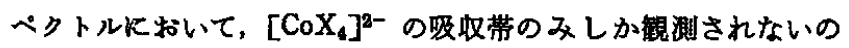
は, チオシアナト錯体について述べたと同じ理由による。

\section{4 バラジウムおよび白金錯体}

赫吸収スペクトルにおいて， עO-H または $\nu_{\mathrm{N}-\mathrm{H}}$ に基づくと 考えられる吸収は存在せず，酸アミド基が空素で配位しているこ とが示されるため，これらの錯体は $\mathrm{H}[\mathrm{MCl}(\mathrm{mdp})]$ と表わされ る(図 $6 \mathrm{~A}$ )。この式の水素イオンの状態は明確ではないが, $1200 \sim 450 \mathrm{~cm}^{-1}$ Kわたる異常な幅広い吸収は, その水索イオンの 存在が原因であろら。

パラジウム錯体 [10] のジメチルスルホキシド- $d_{\mathrm{a}}$ 溶液の核磁 気共鳴スペクトル（因 5 ）は， $\delta=9.25 \mathrm{ppm}(1 \mathrm{H})$ に幅広い四重 線 $(J \fallingdotseq 5 \mathrm{~Hz})$ を示す。さらにピリジン環の水素は $\delta=8.3 \sim 7.4$ $\operatorname{ppm}(3 \mathrm{H})$ K, メチル基のシグナルは $\delta=2.96(1.5 \mathrm{H}), 2.88$ $(1.5 \mathrm{H}), 2.74 \mathrm{ppm}(3 \mathrm{H})$ K分裂して現われる。9.25 ppm のシ グナルが四重線に分裂しているのは，メチル基とのカッブリング による可能性がある。また 2.96 と $2.88 \mathrm{ppm}$ のシグナルは約 $5 \mathrm{~Hz}$ の差があり, カップリングがないとき $2.92 \mathrm{ppm}(3 \mathrm{H})$ 飞観 測されるべきシグナルが，カップリングにより分裂したと考えら れる。すなわら、9.25 ppm の水素がメチル基の一方とカップリ ング $(J=5 \mathrm{~Hz})$ をしているためで, 配位していない $\mathrm{mdpH}_{2}$ の スペクトルとの比較から、ジメチルスルホキシド液液中では, 固 体のとき（図 6A）とは異なる構造（図 6B) であると思われる。

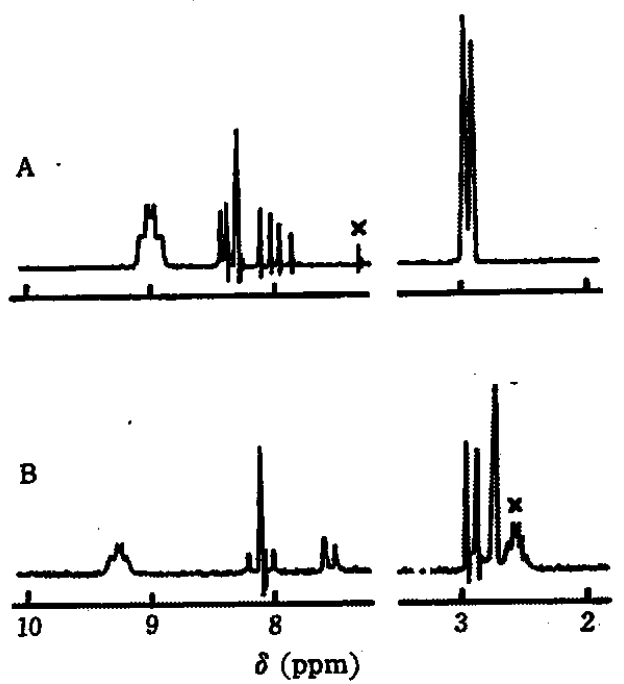

Fig. 5 PMR spectra

$A: \mathrm{mdpH}_{2}$ (in $\mathrm{CDCl}_{8}$ ), B: $\mathrm{H}[\mathrm{PdCl}(\mathrm{mdp})]$ (in DMSO- $d_{6}$ ) $X$ : Solvent absorption

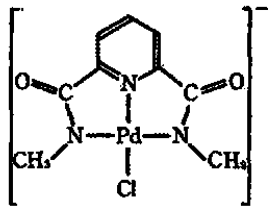

A<smiles></smiles>

B
Fig. 6 Proposed structures for $\mathrm{H}[\mathrm{PdCl}(\mathrm{mdp})]$ in solid (A) and in a DMSO solution (B)

\section{5 括}

2-ピリジンカルバルデヒド-2'-ピリジルヒドラゾンや2, $2^{\prime}, 2^{\prime \prime}$ テルピリジンが $\mathrm{MX}_{2} \mathrm{~L}$ で表わされる五配位鑤体を生ずるのに対 して, $\mathrm{mdpH}_{2}$ す同 $\mathrm{L} 1: 1$ 錯体を与えるが, エハルトは八面体 と四面体との鍺イオン, $\left[\mathrm{M}\left(\mathrm{mdpH}_{2}\right)_{2}\right]\left[\mathrm{MX}_{4}\right]$ からなり，銅およ びニッケルはXで濿かけした二量体となり，ともに五配位の檴造 とはならなかった。一方，垉基性溶液中ではニッケルと銅は酸了 ミド基が窒素で配位したと思われる色を呈するが，生じた錯体は 不安定で単離できなかった。しかし，バラジウムおよび白金て は，アルカリを加えないでも酸アミド基が水素を失い，窒莱で四 位した錯体を単教することができる。パラジウム錯体はジメチル スルホキシド溶液中で情造变化を起こし，一方の动アミド基が 酸意で配位する。ささらに mdpH 錯体結晶中に取りこまれるが,‘これは配位能力が弱いためと思わ れる。

核䃄気共鳴スヘクトルは，当教室の反応有機化学研究室の荘罢 を，拡射反射スベトルは同位体化学研究室の Zeiss PMQ-II 㤠

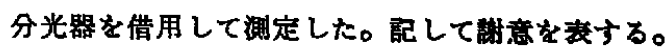




\title{
Bivalent Metal Complexes of $N, N^{\prime}$.Dimethyl-2,6-pyridinedicarboxamide \\ Matsuo Nonoyama, Yukio Tomomoto and Kazuo Yamasaki \\ Inorganic Chemical Laboratory, Faculty of Science, Nagoya \\ University ; Chikusa-ku, Nagoya-shi, Japan
}

Cobalt (II), nickel (II), copper (II), palladium (II), and platinum (II) complexes of $N, N^{\prime}$ dimethyl-2,6-pyridinedicarboxamide (abbreviated as $\mathrm{mdpH}_{2}$ ) were prepared (Table 1) and studied on the structures by means of infrared, electronic, and pmr spectra and further magnetic susceptibilities were determined (Tables 2,3 , and 4 , and Fig. 5). The ligand $\mathrm{mdpH}_{2}$ is potentially terdentate and coordinates through nitrogen atom of pyridine, and two oxygen or two nitrogen atoms of the amide group. The mode of coordination of the amide group is distinguished by infrared spectra. The complexes prepared are classified as the following three types; A: $\mathrm{MX}_{2}\left(\mathrm{mdpH}_{2}\right) \cdot n \mathrm{H}_{2} \mathrm{O}(\mathrm{M}=\mathrm{Co}, \mathrm{Ni}, \mathrm{Cu}$ and $\mathrm{X}=\mathrm{Cl}, \mathrm{Br}), \mathrm{M}\left(\mathrm{mdpH}_{2}\right)_{2}\left(\mathrm{ClO}_{4}\right)_{2} \cdot 2 \mathrm{H}_{2} \mathrm{O}(\mathrm{M}=\mathrm{Ni}$, $\mathrm{Cu})$; $\mathrm{B}: \mathrm{M}(\mathrm{NCS})_{2}\left(\mathrm{mdpH}_{2}\right)_{2} \cdot 4 \mathrm{H}_{2} \mathrm{O}(\mathrm{M}=\mathrm{Co}, \mathrm{Ni}), \mathrm{Co}\left(\mathrm{mdpH}_{2}\right)_{4}\left(\mathrm{ClO}_{4}\right)_{2} \cdot 10 \mathrm{H}_{2} \mathrm{O} ; \mathrm{C}: \mathrm{H}[\mathrm{MCl}(\mathrm{mdp})]$ $\left(\mathrm{M}=\mathrm{Pd}, \mathrm{Pt}\right.$ ). In the type $\mathrm{A}$ complexes, the ligand $\mathrm{mdpH}_{2}$ is coordinated through the pyridine- $\mathrm{N}$ and the two amide- $\mathrm{O}$ atoms. In the type $\mathrm{B}$ complexes, the ligand does not seem to be coordinated and it is only incorporated in the crystal lattice of the host metal salt, since any shift of the amide band and the band of the pyridine ring at $648 \mathrm{~cm}^{-1}$ from that of the free ligand is not observed. In the type $\mathbf{C}$ complexes, the amide groups are coordinated through deprotonated nitrogen, which is indicated by the two strong characteristic bands at ca. 1600 and $1400 \mathrm{~cm}^{-1}$, and the absence of $\nu_{\mathrm{N}-\mathrm{H}}$. The structure of these complexes is square planar with the coordination of a chloride ion (Fig. 6). No complex of this type was isolated except in the case of palladium and platinum.

\section{ポリアミン-N-ポリ酢 酸一鉄 (III) 錯 体 と インジウム（III）との 置換反応}

(1971 年 10 月 19 日受理)

\author{
野 犄 亨・春 日 邦 宣・小柴 訓 治*
}

$\mathrm{pH} 1.5 \sim 3.0, \mu=0.1,20^{\circ} \mathrm{C}$ ての水溶液中で, $260 \mathrm{~m} \mu$ ての吸光度の䄳時変化を測定して, EDTA 類似の EDTAOH, GEDTA, DTPA の鉄（III）錯体とインジゥム（III）との圈換反応速度を謤べ, EDTA-OH，DTPA 系の正，逆 两反応速度式を，GEDTA 系の正反応速度式をそれぞれ求めた。各反応径路の全反応速度に対する寄与率を計算した 結果, EDTA-OH, GEDTA 系正反応江錯体の解離段階が律速である解崔径路を経て, DTPA 系正反応は複核中間 体生成䎠程を経て，EDTA-OH，DTPA 系逆反忘は両径路を経て進行することが推定された。また，In(III)-EDTA-

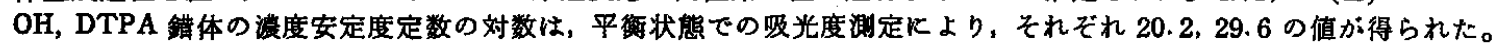

\section{1 粕霉}

多座配位子エチンンジアミン四酭酸 (EDTA), ニトリロ三酢酸 (NTA) あるいは 1,2-シクロヘキサンジアミン四酢酸 (CyDTA)

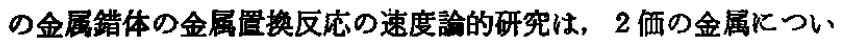
ては田中ら ${ }^{1) 2)}$ Kよりポーシログラフ法で，その後 Margerum，

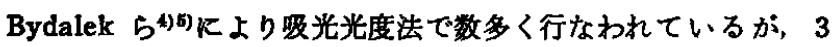

* 爱嫒大学工学部工羛化学科, 松山市文京町

1) N. Tanaka, K.Kato, R. Tamamushi, Bull. Chem. Soc. Jap., 31, 283(1958).

2) 高橋展男，小磯武夫，田中傮行，日化，91，236(1970).

3) D.W.Margerum, J.Phys. Chem., 63, 336(1959).

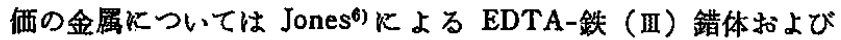
斎藤》)の $N-$ (ヒドロキシエチル)エチレンジアミンー $N, N^{\prime}, N^{\prime}-三$ 酸酸 (EDTA-OH) のインジウム（III）錯体の放射性同位体交換 反応が見られる程度で，他種金属との畺換反応は見られない。

著者らは紫外分光光度法によるポリアミンー $N$-ポリ酢酸 $\mathrm{H}_{n} \mathrm{X}$

4) T. J.Bydalek, D. W. Margerum, J. Amer. Chem. Soc., 83, 4326(1961).

5) T. J. Bydalek, M. L. Blomster, Inorg. Chem., 3, 667 (1964).

6) S.S.Jones, F.A.Long, J. Phys.Chem., 56, 251 (1952).

7) K.Saito, M. Tsuchimoto, Bull.Chem.Soc. Jap., 36, 367 (1962). 